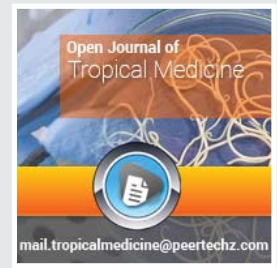

Medical Group

\title{
Open Journal of Tropical Medicine
}

\section{Eddaikra $\mathrm{N}^{1-3 *}$, Ait-Oudhia $\mathrm{K}^{4}$, Oury $\mathrm{B}^{2,5}$, Moulti-Mati Farida ${ }^{3}$, Harrat $Z^{1,6}$ and Sereno $D^{2,5}$}

${ }^{1}$ Laboratory of Parasitary Eco-epidemiology and Genetics of Populations, Pasteur Institute of Algiers, Petit Staoueli Road Dely Brahim, Algiers, Algeria 2Joint Research Unit IRD 224 MiVegec (Infectious Diseases and Vectors: Ecology, Genetics, Evolution and Control), Research Institute for Development (IRD), PO Box 64501, 34394 Montpellier cedex 5, France

${ }^{3}$ Laboratory of Analytical Biochemistry and Biotechnologies, Mouloud Mammeri University of Tizi Ouzou, Algeria

${ }^{4}$ National Veterinary Superior School, PO Box 161, Hassan Badi El-Harrach, Algiers, Algeria

5IRT Research Unit 177 InterTryp ("Hosts-VectorsParasites-Environment Interactions in Neglected Tropical Diseases Caused by Trypanosomatids"), Research Institute for Development (IRD), BP 64501, 34394 Montpellier cedex 5, France

${ }^{6}$ Laboratory of Biodiversity and Environment: Interactions, Genomes (LBEIG) of the Faculty of Biological Sciences of the University of Science and Technology Houari Boumediene (USTHB) of Algiers, Algeria

Dates: Received: 19 September, 2017; Accepted: 27 September, 2017; Published: 28 September, 2017

*Corresponding author: Eddaikra N, Laboratory of Parasitary Eco-epidemiology and Genetics of Populations, Pasteur Institute of Algiers, Petit Staoueli Road Dely Brahim, Algiers, Algeria, Tel/Fax: +213 21341920 ; +213 772366699; E-mail:neddaikra@yahoo.fr

Keywords: Leishmaniosis; Algeria; Drug resistance; Antimony

https://www.peertechz.com

\section{Review Article \\ Leishmania antimony resistance/ susceptibility in Algerian foci}

\section{Abstract}

Algeria is one of the most endemic countries for cutaneous and visceral forms of leishmaniosis. Strikingly, with more than 21,000 annual cases of cutaneous leishmaniosis recorded in 2010 , the disease has a major public health impact. For all forms of leishmaniosis, the first line treatment relies on antimonial containing drug i.e., Glucantime ${ }^{\circledR}$, developed during the 1950 's. As early as 1986 , antimonial treatment failure was reported during cutaneous leishmaniosis treatment. Linked to this therapeutic failure, Leishmania strains displaying a low susceptibility towards antimonials were isolated. Nevertheless, in Algeria, antimonial formulations still remain the first line drug for all clinical forms of leishmaniosis. Therefore, an urgent need of knowledge on the baseline antimony susceptibility status of parasites strains in Algeria is required. These pieces of knowledge will shed light not only on the prevalence of antimony resistance in this area but also on underlying factors triggering this drug resistance in natural populations. Here, we performed a review of the literature on what is known about epidemiology, treatment failure, and antimony-resistance, in Algeria. We bring information on underlying mechanisms acting in antimony resistant parasites and discuss their potential to be used for diagnostic purpose. This analysis will help to set up protocols aiming at detecting antimony resistant strains in Algeria and to test the risk of transmission, two steps that are essential to define public health policy in Algeria.

\section{Introduction}

Leishmania sp. are causative protozoal agents of various forms of leishmaniosis, which is a significant cause of morbidity and mortality in more than 98 countries and territories [1]. The clinical manifestations of leishmaniosis range from various cutaneous forms to a fatal visceral form. In the Mediterranean Basin, anthroponotic cutaneous leishmaniosis (ACL) caused by Leishmania tropica, zoonotic cutaneous leishmaniosis (ZCL) caused by Leishmania major or, less frequently Leishmania infantum and zoonotic visceral leishmaniosis (ZVL) caused by L. infantum are endemic. Visceral leishmaniosis is widely distributed around the Mediterranean Basin, unlike ZCL and ACL which are more restricted to the southern and oriental regions. In South America, ZCL caused by various Leishmania species (e.g., Leishmania mexicana, Leishmania (Vianna) peruviana, Leishmania (Vianna) guyanensis, Leishmania (Vianna) panamensis and others), mucocutaneous leishmaniosis caused by Leishmania (Vianna) braziliensis, diffuse cutaneous leishmaniosis caused by Leishmania amazonensis and Leishmania mexicana and ZVL caused by Leishmania infantum, are all highly endemic. In the Indian subcontinent, anthroponotic visceral leishmaniosis (AVL) caused by Leishmania donovani poses a major health problem. In several regions of the world, the incidence of leishmaniosis outbreaks has been associated with urbanization, travel, climatic change and social conflicts $[2,3]$.

In the absence of effective vaccines, the only feasible way to treat and control leishmaniosis is through the use of affordable medications. The current chemotherapeutic arsenal consists of molecules developed in the 1950s', including pentavalent antimony $(\mathrm{Sb}(\mathrm{V}))$ compounds (e.g., Pentostam ${ }^{\circledR}$, Glucantime $\left.{ }^{\circledR}\right)$, pentamidine and various formulations of the antifungal Amphotericin B and, more recently, miltefosine [47]. The choice of the chemotherapeutic protocol is frequently dictated by economic considerations instead of being based on clinical or biological indications. Therefore, antimonial containing drugs, one of the most affordable molecules, are in clinical use to treat all forms of leishmaniosis in most part of the word [8]. Therapeutic failure during antimony treatment remains a well-known problem, but antimony resistance is not the only factor responsible for the therapeutic failure. Indeed, 
factors that are linked to the host (e.g., immunosuppression or malnutrition), the drug itself (e.g., drug batch or counterfeit drugs), the Leishmania species, the practitioner or the patient (e.g., incomplete treatment follow-up) will also play a role in parasite drug resistance and treatment failure $[4,9,10]$. In most parts of the world, the frequency of parasite antimony resistance linked to treatment failure is unknown $[4,9,10]$. This information should be crucial to address the risk of selection and transmission of drug-resistant parasites, particularly in areas where antimony is the only chemotherapeutic alternative. Here we review the current epidemiological situation of leishmanioses in Algeria, address available tools to diagnose antimony resistance and, then focus on ongoing researches about antimony resistance in this area.

\section{Update on past and current epidemiological data}

The first case description of leishmaniosis in Algeria was carried out by the Sergent brothers almost a century ago [11].

\section{Human visceral and cutaneous leishmanioses}

In Algeria, three distinct clinical forms of leishmaniosis are encountered. In the Sahara and the highland regions, the zoonotic form of leishmaniosis, caused by L major (ZCL), is endemic (Figure 1). Two variants of L. major, zymodeme MON25, and zymodeme MON-269 are reported to be present in Algeria $[12,13]$. The insect vector for L. major is Phlebotomus papatasi [14], and the wild rodents Psamommys obesus and Meriones shawi are the reservoir hosts of the parasite $[15,16]$. Moreover, natural infection of hedgehogs with L. major was reported [17].

In the central part of the country and particularly in the oasis of Ghardaia, the chronic form of cutaneous leishmaniosis is due to $L$ killicki. L. killicki belongs to the L tropica complex and generally occurs in sympatry with L. major $[18,19]$. The annual incidence of this peculiar form of cutaneous leishmaniosis is

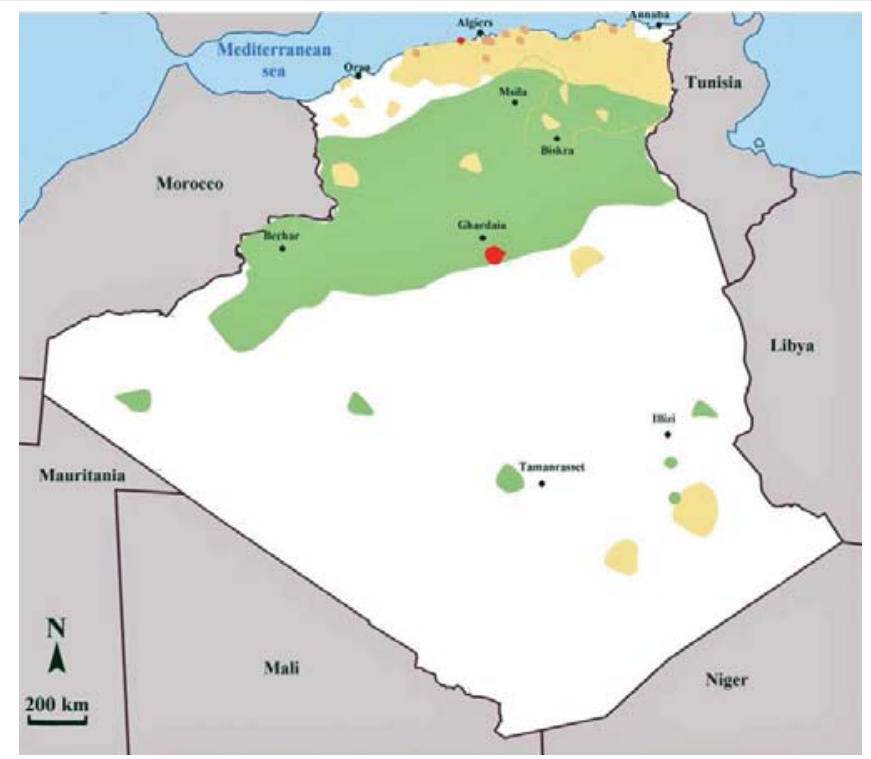

Figure 1: Distribution of cutaneous and visceral leishmaniosis in Algeria. (•)

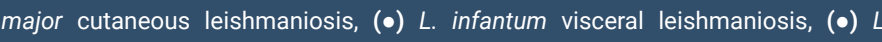
infantum cutaneous leishmaniosis, (•), L. killicki cutaneous leishmaniosis. estimated to be less than 100 cases per year, in Algeria. The proven vector for L. killicki is Phlebotomus sergenti [20], and the suspected reservoir host is Massoutiera mzabi, a rodent close to Ctenodactylus gundi that has been found naturally infected with L. killicki in Tunisia [21]. In the northern part of the country, a zoonotic cutaneous form caused by $L$ infantum is sporadic. The proven vector is Phlebotomus perfiliewi [22], and the variant L. infantum MON-24 [23], responsible for this cutaneous form, is present in dogs, the animal reservoir of this species. The visceral form of leishmanioses caused by L. infantum occurs mainly in the northern part of the country. The active visceral leishmaniosis foci are located in the region of Kabylie in the north of the country as well in the east in the departments of Jijel and Constantine. Some cases are also reported in the south, in Tassili N'ajjer and the Hoggar mountains in Illizi and Tamanrasset respectively [24]. The proven vector of $L$. infantum in Algeria is Phlebotomus perniciosus and canids, dogs and jackals are the main reservoirs $[12,25]$.

Currently, an emerging focus of cutaneous leishmaniosis in the northern part of Algeria is reported [26]. Parasitological investigations carried out from 2004 to 2010 have confirmed L. major (zymodeme MON-25) to be the etiological agent of this outbreak, with Psammomys obesus as the main reservoir of the parasite. An entomological survey performed in 2009 pinpointed the predominance of two species of sandfly in this area: Phlebotomus papatasi and P. perniciosus. Therefore, cutaneous leishmaniosis caused by L. major is no longer confined to the central and southern part of Algeria but has spread from the arid zones towards the semi-arid areas, particularly in the Soummam valley. Climate changes and desertification observed in the steppe area of northern Sahara could have played a role in the extension of the disease [27].

\section{Canine leishmanioses in Algeria}

Since 1908 it is recognized that the dog plays a major role in the life-cycle of Leishmania infantum [28]. Various sandfly species belonging to the genus of Phlebotomus act as vectors of the parasite [29]. Canine leishmaniosis (CanL) is a cosmopolitan disease with a worldwide distribution, mainly in tropical areas, but also in the temperate zones of North Africa, Europe, and Asia [30]. The Mediterranean basin is particularly affected and the disease is reported in almost all the countries bordering the Mediterranean, with relatively variable prevalence. In Algeria, the general prevalence of CanL has been under $11 \%$ for many years, it has recently increased to $25.1 \%$ in 2006 [31]. This increase in the prevalence of canine infection was followed by an increase in human leishmaniosis cases. In the region of Algiers for example, 12.2\% more cases of human visceral and cutaneous leishmaniosis were recorded between 1990 and 1997 [32,33]. Until the 1980s', the prevalence of infection amongst dogs of Algiers was always below $10 \%$. It is only in the last decade that the prevalence markedly increased, to reach $30 \%$ in the 1990 s' $^{\prime}$ and $20 \%-25 \%$ in the 2000 s'. $^{\prime}$ This change may be mainly explained by the concurrent and dramatic environmental changes that have occurred in Algeria, particularly the uncontrolled urbanization that took place in recent years. This new urbanization has led to a proliferation of 
dogs around the houses and the removal of natural vegetation. That has possibly driven vectors to invade the peridomestic and intra-domiciliary habitats. Six zymodemes were identified in Algeria: MON-1, MON-24 and MON-281 in Algiers, MON-34, and MON-77 in Grande Kabylie [23,31,34-36]. An exhaustive view of the Leishmania infantum zymodemes isolated and characterized in human and dogs, around the Meditarrean basin are presented in figure 2 .

\section{Treatment, chemotherapeutic failure and drug-resis- tance in Algeria}

Pentavalent antimonial compounds remain the first line treatment against both cutaneous and visceral forms of leishmaniosis in North Africa. In Algeria, care for leishmaniosis is provided for free by health structures. The diagnosis of CL takes place at health center level but visceral forms are diagnosed in hospitals. Meglumine antimoniate and conventional amphotericin B are included in the National Essential Drug List. The protocol recommended by the Ministry of Health, for the treatment of all forms of cutaneous leishmaniosis consists in the administration of $20 \mathrm{mg} / \mathrm{kg} /$ day Glucantime ${ }^{\circledR}$ (pentavalent antimony $(\mathrm{Sb}(\mathrm{V}))$ for 15 consecutive days, by intramuscular injection, when multiple lesions are observed, or if the lesion is located on the face. For single lesion, the Ministry of Health recommends the intradermic (intralesional) administration 1.5 to $2 \mathrm{ml}$ of Glucantime ${ }^{\circledR}$ twice per week for 4 weeks. Hydrogen peroxide $\left(\mathrm{H}_{2} \mathrm{O}_{2} 10 \mathrm{vol}\right)$ or cryotherapy is also used to treat cutaneous lesions as alternative treatments.

For VL, intramuscular injection of Glucantime ${ }^{\circledR}$ (20 mg $\mathrm{Sb}(\mathrm{V}) / \mathrm{kg} /$ day) for 28 days is recommended by the ministry of health, following the protocol recommended by the World Health Organization. In case of unresponsiveness, intravenous perfusion of amphotericin B (Fungizone ${ }^{\circledR}$ ) in a dose of $1 \mathrm{mg} / \mathrm{kg} /$ day for 15 days is recommended.

In Algeria, unresponsiveness to $\mathrm{Sb}(\mathrm{V})$ to the treatment of

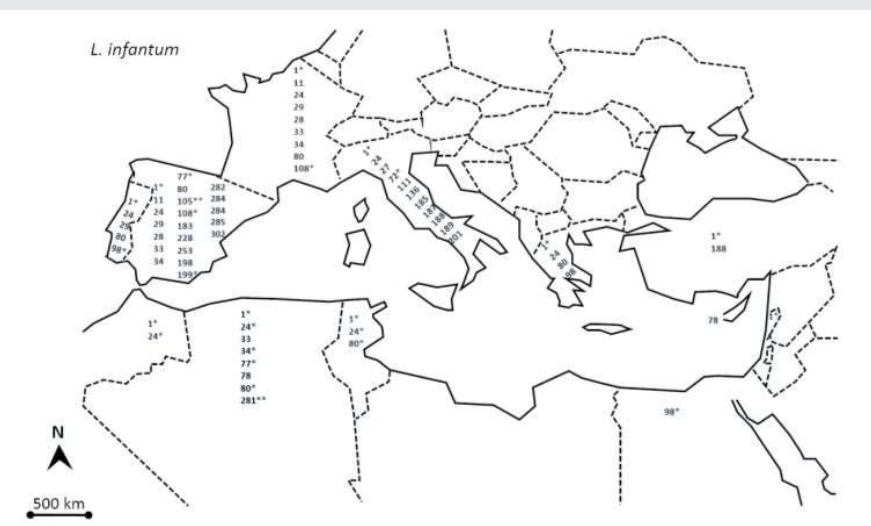

Figure 2: Distribution of $L$. infantum variants responsible for canine and human visceral leishmanioses, around the Mediterranean basin. Between 1973 and 2010, numerous human and canine $L$. infantum isolates were collected in 15 countries excepted in Algeria, bordering the Mediterranean sea. Parasites were typed by multilocus enzyme electrophoresis (MLEE), according to the protocol previously described by Rioux et al. (1990), using 15 enzymatic systems. The numbers represent the zymodemes. $\left(^{*}\right)$ Only 12 zymodemes out of 37 reported in human were found in dogs, namely MON-1, MON-11, MON-24, MON-27, MON-30, MON-34, MON-77, MON-98, MON-108, MON-267, MON-278 and MON-281. (**) only found in dog. zoonotic cutaneous leishmanioses is well documented in the focus of M'sila. In 1986 a survey carried out on ninety-seven children who received $60 \mathrm{mg} / \mathrm{kg} /$ day of meglumine antimoniate for 15 days, reported no significant response compared to those receiving placebo. In vitro tests performed on intracellular amastigotes confirmed that all the strains of L. major isolated from these children displayed a low susceptibility towards $\mathrm{Sb}$ (V) containing drugs in the form of Glucantime ${ }^{\circledR}$ [37]. More recently, $9 \%$ of unresponsiveness to antimonial treatment was recorded in children with visceral leishmaniosis $[38,39]$.

For the veterinarian practitioners, treatment of canine leishmaniosis remains difficult, given the complex pathogenesis of the disease associated with pleiotropic clinical signs [40]. All antileishmanial compounds in use to treat dogs can lead to temporary or permanent remission of clinical signs but no established protocol is effective to eliminate the infection. While therapeutic protocols have evolved the drugs used for treatment haven't changed. In case of a confirmed diagnosis, the practitioner has firstly to worry about the risks of transmission to man and then about chances of curing of the animal [41]. Infected dogs are often treated with the same drug used for humans. The treatment with antimonials is often long and costly and the toxicity of antimony causes serious side effects $[42,43]$. Currently, the association of meglumine antimoniate with allopurinol is used [43,44]. In Algeria, dog suffering of leishmaniosis is usually not treated. Therefore, there are no available data on treatment efficiency. So as in other countries endemic for the leishmaniosis, veterinarian practitioners euthanize dogs diagnosed as positive in order to prevent the spread of the disease to humans.

In the occidental part of the Mediterranean basin where dogs are commonly treated with meglumine antimoniate, the occurrence of resistant strains to antimony is documented [45]. We recently highlighted the occurrence of antimonyresistance in strains belonging to the L. infantum MON-281 [46] and further probed their potential of being transmitted by sandflies [47]. We also checked for cross-resistance with other molecules in clinical use to treat the visceral leishmaniosis $[2,46,48]$. To clarify the risk of transmission of antimonyresistant strains in Algeria, it will be crucial to determine the prevalence of the peculiar zymodeme MON-281 circulating in the canine population. To shed light on the underlying factor that may act to select for antimony resistance, we have begun to assess and compare the in vitro antimony susceptibility status of strains originating from two geographic areas, differing in their history of antimony pressure. A sample of 48 and 20 strains isolated from humans, dogs or sandflies during the last 30 years, in Algeria and France respectively, was selected in the Biobank of the Pasteur institute of Algiers and the National Reference Center for Leishmania in Montpellier. The antimony susceptibility status of strains was tested on promastigotes. Interestingly, L. infantum strains isolated in Algeria were found to be significantly less susceptible toward antimony than strains isolated in France $(\mathrm{p}<0.001$, unpaired t-test) (Figure 3) (Eddaikra et al., unpublished results). The selection for antimony resistance was recently demonstrated to confer fitness advantages $[49,50]$. This finding will likely have 


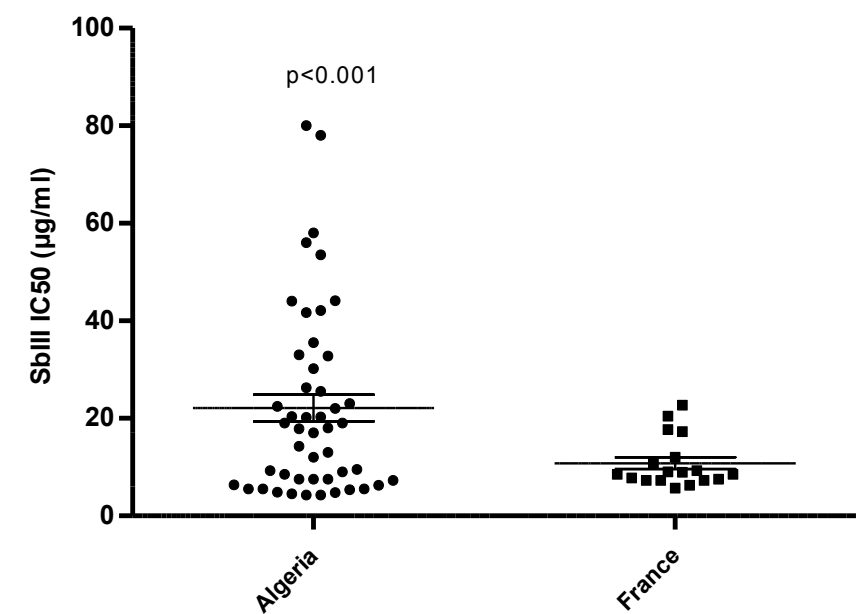

Figure 3: Antimony susceptibility status of $L$. infantum strains isolated in Algeria and France. Susceptibility $\left(\mathrm{IC}_{50}\right)$ toward trivalent antimony of Leishmania infantum MON1 promastigotes isolates sampled in Algeria and France.

to result in the prioritization of studies aimed at diagnosing antimony resistance in Leishmania.

\section{Available tools to monitor parasite antimony suscepti- bility}

Various hosts and antimony-derived molecules play a role in the antileishmanial activity of $\mathrm{Sb}(\mathrm{V})$ in vivo. Therefore, ideally, to reflect the in vivo activity of antimonials, the in vitro tests must monitor the antileishmanial activity of compounds playing a role in the killing pathway of $\mathrm{Sb}(\mathrm{V})$. In addition, the origin of the antimonial batch has to be taken into account, because commercially available $\mathrm{Sb}(\mathrm{V})$ solutions are not pure $[4,51]$. In fine in all cases, the IC50 determined in vitro must always be compared with clinical observations. In most laboratories, the screening for leishmanicidal compounds is carried out with Leishmania promastigotes. However, the best approach is to test leishmanicidal compounds toward amastigotes residing in macrophages.

\section{Cellular models for in vitro testing antimonial suscepti- bility}

Obviously, the intracellular amastigotes represent the ideal model because both the indirect activity, through the host cell, and the direct one on the parasite can be assessed. Unfortunately, methods that involve intracellular amastigotes are labor intensive, difficult to standardize and timeconsuming. In addition, the results are dependent upon the nature of the host cell used to grow Leishmania amastigotes [52-54]. Duplex quantitative reverse-transcriptase PCR (qRTPCR), aimed at assessing drug activity against Leishmania intracellular amastigotes and their host cells can be performed. The assay simultaneously quantifies Leishmania $18 \mathrm{~S}$ ribosomal RNA and the human b2-microglobulin (b-2M) mRNA, used for monitoring drug cytotoxicity and test performance [55]. Nevertheless, this approach is time-consuming, cost prohibitive and not amenable to large-scale analysis. The development of reporter gene technologies has enabled the quantification of Leishmania parasites in host cells and whole mammalian hosts [56-59]. These technologies have been tested to determine the drug susceptibility of field isolates $[60,61]$. However, the time required for transfection and the selection of recombinant parasites certainly affect the composition of the isolates in mixed Leishmania infections [62]. But the lack of consensus in the standardization of this methodology makes interpretation of potential intra- and interspecific variations in antimony susceptibility difficult. In fact, even if this reporter-based method takes into account all the factors that are involved in intracellular $\mathrm{Sb}(\mathrm{V})$ antileishmanial activity, its versatility and cost make its application very impractical for large-scale analysis of parasite antimony susceptibility and resistance surveys. More recently high content imaging proved to be useful for antileishmanial agent discovery [63], since no reporter gene is used to monitor the intracellular parasite multiplication. This technology should represent the future for antimonial susceptibility phenotyping of natural Leishmania populations.

A large number of Leishmania species can be grown in vitro as amastigotes under axenic conditions $[64,65]$. The determination of drug activity is simple, typically inexpensive and does not require host cells, which makes standardization easier. Various studies showed a similarity of protein contents in axenic amastigotes and intracellular ones. In addition, axenic amastigotes seem much more infective and grow more easily than those isolated from macrophages-derived cells. Axenic macrophages can be also differentiated in vitro directly from the promastigote stage. However, as for the reporter gene technology, the duration of the differentiation, the capacity of strains to be differentiated and their representation in the initial isolate to be tested may select strains pre-adapted to the differentiation into amastigotes and consequently modify the composition of isolates in mixed infections. Indeed, not all Leishmania species or strains are amenable to being cultured in axenic conditions. Currently, no extensive studies using axenic amastigote cultures have been performed to evaluate the antimony susceptibility of field isolates.

The usefulness of promastigotes to ascertain the antimony susceptibility status of Leishmania field isolates has been debated. The trivalent form of antimony (Sb (III)) is used to test the susceptibility of promastigotes because this stage is weakly susceptible to the pentavalent antimony. Unfortunately, the susceptibility of promastigotes to trivalent forms of antimony does not always reflect the sensitivity of intramacrophagic amastigotes to pentavalent antimonial formulations $[66,67]$. Nevertheless, various experimental reports that used L. tropica, L. infantum or L. donovani support the notion that Sb (III) susceptibility of promastigotes partially reflects the intrinsic $\mathrm{Sb}$ (V) susceptibility of amastigotes within macrophages [68-70]. Because the host cell is omitted in tests that use promastigotes, we hypothesized that the discrepancies observed between experiments might reflect the differential role of the hostderived microbicidal factors involved in the $\mathrm{Sb}(\mathrm{V})$-induced intracellular killing. Most of these drug or host-derived factors are currently identified, but tests aimed at simultaneously ascertaining the intrinsic susceptibility of promastigotes to antimonials might be more representative. 


\section{Animal models for in vivo antimonial susceptibility test- ing}

Animal models have been largely used to study the biological and pathological features specific to cutaneous and visceral leishmaniosis, even that none can reproduce the various syndromes encountered in humans. Current animal models aim at investigating (i) host-parasite interactions by the way of pathogenesis or biochemical and biological changes, (ii) in vivo maintenance of parasites and (iii) clinical evaluation of drug candidates.

The principal problem of using animal models to explore antimony activity is the route of administration and the distribution to different sites of infection. Several animal species served as experimental hosts especially for CL: BALB/c mice and Syrian golden hamster, dogs and monkeys $[71,72]$. The choice of convenient animal models depends on Leishmania species under study. For instance, the most suitable animal models are C57BL/6 mice (or vervet-monkeys, or rhesus-monkeys) for $L$. major and CsS-16 mice for L. tropica. CBA mice are convenient to study physiopathological effects caused by the infection with $L$. amazonensis and CBA and golden hamsters or rhesus-monkeys can be used for L. braziliensis ${ }^{71}$. We have recently established a murine model for Leishmania killicki cutaneous infections and probed its suitability for pharmacological purposes [73]. This new model will now enable us to investigate the in vivo behavior of this emerging pathogen, under antimony in vivo antimony pressure.

\section{Biomarkers for antimony resistance}

The search for resistance biomarkers is based on the indepth understanding of the antileishmanial mode of action of antimony (Figure 4) and resistance associated with in vitro selection [74]. Studies on the intracellular mode of action of $\mathrm{Sb}$ (III) demonstrates that thiol buffer capacity of Leishmania is deeply affected by $\mathrm{Sb}(\mathrm{III})$, through the inhibition of the trypanothione reductase [75], and via a decrease in the intracellular thiol content through an efflux mechanism yet unidentified [76]. These two mechanisms combine to profoundly compromise the thiol redox potential in drugsensitive parasites and lead ultimately to the accumulation of reactive oxygen species ROS [76,77].

Many of the specific genes associated with resistance to antimony have been discovered. These mechanisms generally involved:

The limiting antimony entry into the cell. The entry of Sb (III) occurs through an AQP1 transporter [78], but the route of entry of $\mathrm{Sb}(\mathrm{V})$ is currently not identified.

The increase of the target expression. Sb (III) inhibits the Trypanothione reductase activity leading to an accumulation of the reduced form of trypanothione. Overexpression of the Trypanothione reductase has been characterized in most of the antimony-resistant field isolates [79], with some exceptions [80].

The decrease of the reduction of the prodrug form of $\mathrm{Sb}$, $\mathrm{Sb}(\mathrm{V})$ to the active form $\mathrm{Sb}(\mathrm{III})$. This function is assumed by

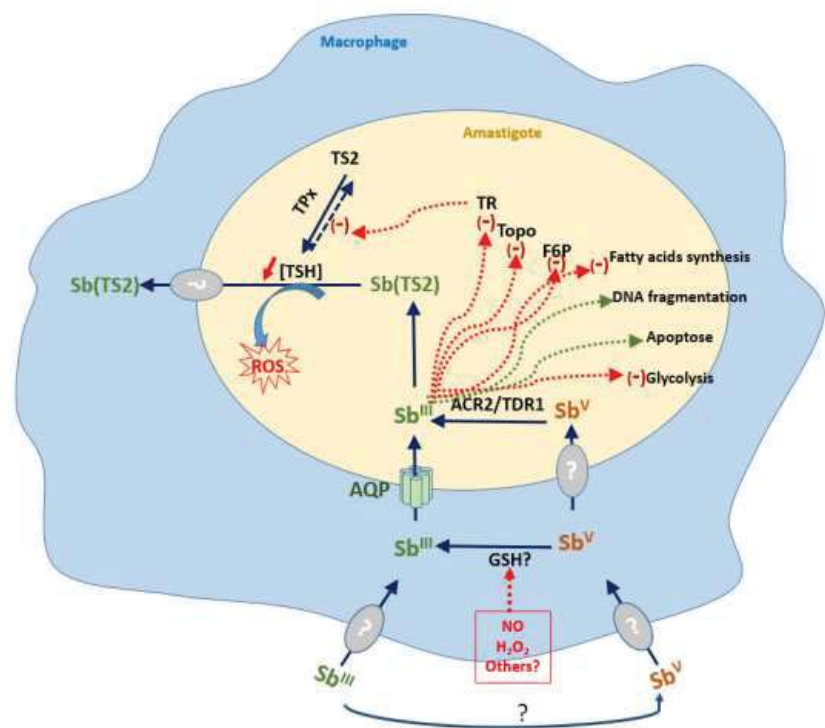

Figure 4: Schematic representation of the proposed mode of action of $\mathrm{Sb}(\mathrm{V})$ containing drugs. The trivalent form of antimony ( $\mathrm{Sb}$ (III) comes from the reduction of the pentavalent form $\mathrm{Sb}(\mathrm{V})$ and constitutes the active form of antimony towards Leishmania. In the host cell, the Host-derived molecules also play a role in the antileishmanial activity of $\mathrm{Sb}(\mathrm{V})$ in vivo. Both species of antimony are able to induce the generation of $\mathrm{NO}$ and $\mathrm{H}_{2} \mathrm{O}_{2}$ that are harmful for intracellular parasites. The entry of $\mathrm{Sb}(\mathrm{V})$ into the parasite occurs by an unknown transporter, and entry of $\mathrm{Sb}$ (III) through AQP1. Within the parasite, $\mathrm{Sb}(\mathrm{V})$ is reduced into $\mathrm{Sb}$ (III) by the action of the reductases, ACR2 (an homolog of the yeast arsenate reductase) and TDR1 (Thiol Dependent Reductase). Beforehand $\mathrm{Sb}(\mathrm{V})$ can be also reduced by Glutathione in the host cell. Sb(III) inhibit various enzymes: the topoisomerase (Topo), the fructose-6 phosphatase (F6P) and the trypanothione reductase (TR). It interferes with the antioxydative defense of the parasite through the inhibition of the trypanothione reductase and the formation of $\mathrm{Sb}$ (III)-TSH complex that is actively exported. These actions led to a drastic reduction in TSH and concomitantly to an accumulation of reactive oxydant species (ROS) toxic for the parasite. Other abbreviations: TPx, Tryparedoxin, TSH, reduced trypanothione; TS2, oxidized trypanothione; Sb(TS)2, conjugate of $\mathrm{Sb}(\mathrm{III})$ with trypanothione.

two reductases, TDR1, a thiol-dependent reductase, belonging to the Glutathione S-transferase family that shares homologies with the T. cruzi Tc52 protein [81], and LmACR2 that shares homologies with arsenate reductases [82]. Nevertheless, variations in reductase capacity of field Leishmania isolates resistant to antimony have never been investigated.

The conjugation of the drug with thiol-containing molecules and sequestration or efflux of the thiol conjugated drug. In all Kinetoplastidae, the major low molecular mass thiol is trypanothione in contrast with most other prokaryotic and eukaryotic cells, which utilize glutathione to maintain the intracellular thiol redox potential and preserve cells from harmful attacks of oxidative compounds. Trypanothione is a glutathione-spermidine conjugate that is formed following several enzymatic steps, via the synthesis of reduced gluthatione (GSH) and its subsequent conjugation to spermidine. Steps in the synthesis of spermidine involve ornithine decarboxylase (ODC) and spermidine synthase. The first step in the biosynthesis of GSH is catalyzed by the $\gamma$-glutamylcysteine synthetase $(\gamma$-GCS) and the glutathione synthase. In the following step, two enzymes specific to trypanosome are involved in the pathway. First, the glutathionylspermidine synthase ligates reduced glutathione (GSH) to spermidine in a conjugate, the glutathionylspermidine. A second Kinetoplastidae-specific 
ligase, the trypanothione synthase conjugates a second GSH to glutathionylspermidine to produce trypanothione. The pool of reduced trypanothione is maintained by the trypanothione reductase (TR) that ensures the thiol redox potential. Consequently, the overexpression of genes that leads to an increase in the intracellular level of reduced trypanothione ( $\mathrm{T}(\mathrm{SH})_{2}$ ), involves the formation of the $\mathrm{Sb}$-trypanothione conjugate $\left(\mathrm{Sb}\left(\mathrm{TS}_{2}\right)\right)$ and its sequestration within a vacuole by the intracellular ABC transporter MRPA [83], or its efflux from the parasite. In that way, the conjugation of $\mathrm{Sb}$ with trypanothione induces antimony resistance by using up free Sb (III) [81], within the amastigote. However, enzyme that conjugate $\mathrm{Sb}$ with trypanothione or other molecules containing thiols, is unknown.

Mutations associated with resistance represent molecular signatures largely used in drug resistance surveillance for other parasitic diseases. For instance, single nucleotide polymorphisms (SNPs) associated with Plasmodium susceptibility to drugs are often good indicators of the clinical drug resistance [84]. Unfortunately, no SNP have been proved to be indicative of antimony resistance in field isolates. But another main mechanism of resistance evidenced in Leishmania consists in genomic rearrangements, which lead to the amplification of resistance genes through homologous recombination between repeated sequences [85]. Amplified genes known to be involved in antimony susceptibility should, therefore, represent good biomarkers for addressing antimony resistance [86].

If some of the above mentioned mechanisms are effectively encountered in resistant strains from the field, any rule could be applied mainly because of the presence of additional unrelated or less specific mechanisms [87-90], or because of other yet unidentified mechanisms of resistance. Nevertheless, significant DNA amplification and/or higher RNA expression occur in a majority of strains having an antimony resistant [91].

Recent metabolomic approaches have been used to investigate parasites displaying different susceptibility to antimony. Interestingly, a hierarchical clustering approach (antimony resistant and susceptible) revealed differences in the metabolite abundance for the drug-resistant and -sensitive clones [92]. However, in this study the sample size was not large enough to conclusively identify drug-resistant parasites. The extensive procedures involved in culturing the parasites, the high cost, the large amount of time required and the need for highly skilled technicians to perform the metabolomic analyses limit their usefulness for antimony susceptibility surveys. But metabolomic studies might provide information on new metabolic markers for monitoring antimony resistance.

\section{Conclusions}

In Algeria, Sb (V) resistant L. major and L. infantum have been isolated from unresponsive patients and animal reservoirs $[37,46]$. Therefore, the emergence of such resistant parasites stressed questions about factors that are acting to select them but also required more knowledge on the risk of their transmission. In order to compare the relative fitness of antimony-resistant and susceptible parasites, it would be interesting to survey the prevalence of both phenotypes over a large period of time. We think that it would be an adequate approach to assess the relevant natural fitness of both phenotypes. The former is essential to study each of the fitness components in more details, in order to understand why the relative fitness between phenotypes differs, (e.g. due to differences in survival, reproduction or transmission $[49,50]$. These studies are of importance for public health policy.

\section{Acknowledgements}

This study was supported in part by the BEST Grant program of IRD doctoral Fellows $(821849 \mathrm{H})$. We are grateful to the Department for Sustain and Training (DSF) of IRD for providing doctoral Fellowship to N. Eddaikra during the period of this study.

\section{References}

1. Alvar J, Vélez ID, Bern C, Herrfero M, Desjeux P, et al. (2012) WHO Leishmaniasis Control Team. Leishmaniasis worldwide and global estimates of its incidence. PLoS One. Link: https://goo.gl/nMigzm

2. Cardenas CM, Sandoval CM, Rofiguez-Morales AJ, Vivas P (2008) Zoonoses and climate variability. Ann N Y Acad Sci 1149: 326-330. Link: https://goo.gl/pH6SLv

3. Akhoundi M, Kuhls K, Cannet A, Votýpka J, Marty P, et al. (2016) A historica overview of the classification, evolution, and dispersion of Leishmania parasites and sandflies. PLoS Negl Trop Dis. Link: https://goo.gl/QqoDUM

4. Croft SL, Sundar S, Fairlamb A (2006) Drug resistance in leishmaniasis. Clin Microbiol Rev 19: 111-126. Link: https://goo.gl/4R76ua

5. Santos DO, Coutinho CE, Madeira MF, Bottino CG, Vieira RT, et al. (2008) Leishmaniasis treatment, a challenge that remains: a review. Parasitol Res 103: 1-10. Link: https://goo.gl/4XW6eF

6. Mondal S, Bhattacharya P, Ali N (2010) Current diagnosis and treatmen of visceral leishmaniasis. Expert Rev Anti Infect Ther 8: 919-944. Link: https://goo.gl/8PWu3z

7. Murray MW (2010) Treatment of visceral leishmaniasis in 2010: direction from Bihar state, India", Future Microbiol 5: 1301-1303. Link: https://goo.gl/RfuWbm

8. Vanlerberghe V, Diap G, Guerin PJ, Meheus F, Gerstl S, et al. (2007) Drug policy for visceral leishmaniasis: a cost-effectiveness analysis, Trop Med Int Health 12: 274-283. Link: https://goo.gl/JcpU4f

9. Croft SL (2001) Monitoring drug resistance in leishmaniasis. Trop Med Int Health 6: 899-905. Link: https://goo.gl/NNguQm

10. Llanos-Cuentas A, Tulliano G, Araujo-Castillo R, Miranda-Verastegui C Santamaria-Castrellon G, et al. (2008) Clinical and parasite species risk factors for pentavalent antimonial treatment failure in cutaneous leishmaniasis in Peru. Clin Infect Dis 46: 223-231. Link: https://goo.gl/XgDNyn

11. Sergent ED, Sergent ET. Kala-Azar : Existence de la leishmaniose chez les chiens d'Alger. Première note. Bull Soc Pathol Exot 1910; 3: 510-511.

12. Harrat Z, Pratlong F, Belazzoug S, Dereure J, Deniau M, et al. (1996) Leishmania infantum and Leishmania major in Algeria. Trans Roy Soc Trop Med Hyg 90 625-629. Link: https://goo.gl/RB4KE]

13. Pratlong F, Dereure J, Ravel C, Lami P, Balard Y, et al. (2009) Geographical distribution and epidemiological features of Old World leishmaniasis foci based on the isoenzymes analysis of 1048 strains. Trop Med Int Health 14 1071-1078. Link: https://goo.gl/XGSLhk 
14. Izri MA, Belazzoug S, Pratlong F, Rioux JA (1992) Isolement de L. major chez Phlebotomus papatasi à Biskra (Algérie). Fin d'une épopée éco-épidémiologique. Ann Parasitol Hum Comp 67: 31-32. Link: https://goo.gl/KtUARi

15. Belazzoug S (1983) Isolation of Leishmania major Yakimoff \& Schokhor 1914 from Psammomys obesus Gretzschmar, 1928 (Rodentia, Gerbillidae) in Algeria. Trans Roy Soc Trop Med Hyg 77: 878. Link: https://goo.gl/SkZwqC

16. Belazzoug S (1986) Découverte d'un Meriones shawi (Rongeur, Gerbillidé) naturellement infesté par Leishmania dans le nouveau foyer de Ksar Chellal (Algérie). Bull Soc Pathol Exot 79: 630-633. Link: https://goo.gl/Tw8uQR

17. Tomás-Pérez M, Khaldi M, Riera C, Mozo-León D, Ribas A, et al. (2014) First report of natural infection in hedgehogs with Leishmania major, a possible reservoir of zoonotic cutaneous leishmaniasis in Algeria. Acta Trop 135: 4449. Link: https://goo.gl/dgqkv1

18. Harrat Z, Boubidi SC, Pratlong F, Benikhlef R, Selt B, et al. (2009) Description of Leishmania close to Leishmania killicki (Rioux, Lanotte et Pratlong, 1986) in Algeria. Trans Roy Soc Trop Med Hyg 103: 716-720. Link: https://goo.gl/WibevM

19. Garni R, Tran A, Guis H, Baldet T, Benallal K, et al. (2014) Remote sensing land cover changes, and vector-borne diseases: use of high spatial resolution satellite imagery to map the risk of occurrence of cutaneous leishmaniasis in Ghardaïa, Algeria. Infect Genet Evol 28: 725-734. Link: https://goo.gl/XK3Vvi

20. Boubidi SC, Benallal K, Boudrissa A, Bouiba L, Bouchareb B, et al. (2011) Phlebotomus sergenti (Parrot, 1917) identified as Leishmania killick hosts in Ghardaïa, south Algeria", Microb Infec 13: 691-696. Link: https://goo.gl/1pN7zm

21. Jaouadi K, Haouas N, Chaara D, Gorcii M, Chargui N, et al. (2011) First detection of Leishmania killicki (Kinetoplastida, Trypanosomatidae) in Ctenodactylus gundi (Rodentia, Ctnenodactilidae), a possible reservoir of human cutaneous leishmaniasis in Tunisia. Parasit Vectors 4: 159. Link: https://goo.gl/Y1BAzM

22. Izri A, Belazzoug S (1993) Phlebotomus (Larroussius) perfiliewi naturally infected with dermotropic Leishmania infantum at Tenes, Algeria. Trans Roy Soc Trop Med Hyg 87: 399. Link: https://goo.gl/MSwZct

23. Benikhlef R, Harrat Z, Toudjine M, Djerbouh A, Bendali-Braham S, et al. (2004) Présence de Leishmania infantum MON-24 chez le chien. Med trop 64: 381 383. Link: https://goo.gl/s7wkVM

24. Benallal K, Gassen B, Bouiba L, Depaquit J, Harrat Z (2013) Entomological investigation following the resurgence of human visceral leishmaniasis in southern Algeria. Acta Trop 128: 518-521. Link: https://goo.gl/3BW1Jx

25. Bessad A, Mouloua K, Kherrachi I, Benbetka S, Benikhlef R, et al. (2012) Leishmania infantum MON-1 isolated from a golden jackal (Canis aureus) in Grande Kabylie (Algeria). Bull Soc Pathol Exot 105: 5-7. Link: https://goo.gl/JJ3ZxZ

26. Institut national de la santé publique d'Algérie (INSP). "REM (Relevé épidémiologique mensuel) from 1980 to 2013.

27. Boudrissa A, Cherif K, Kherrachi I, Benbetka S, Bouiba L, et al. (2012) Spread of Leishmania major to the north of Algeria. Bull Soc Pathol Exot 105: 30-35. Link: https://goo.gl/FcrSmg

28. Dantas-Torres F (2007) The role of dogs as reservoirs of Leishmania parasites, with emphasis on Leishmania (Leishmania) infantum and Leishmania (Viannia) braziliensis. Vet Parasitol 149: 139-146. Link: https://goo.gl/9H97Yw

29. Killick-Kendrick R (1999) The biology and control of phlebotomine sand flies Clin Dermatol 17: 279-289. Link: https://goo.gl/BzjZxM

30. Alvar J, Cañavate C, Molina R, Moreno J, Nieto J (2004) Canine leishmaniasis. Adv Parasitol 57: 1-88. Link: https://goo.gl/3ADNvW

31. Ait-Oudhia K, Lami P, Lesceu S, Harrat Z, Hamrioui B, et al. (2009) Increase in the prevalence of canine leishmaniasis in urban Algiers (Algeria) following the 2003 earthquake. Ann Trop Med Parasitol 103: 679-692. Link: https://goo.gl/ZBmeFP

32. Aït-Oudhia K, Harrat Z, Benikhlef R, Dedet JP, Pratlong F (2011) Canine Leishmania infantum enzymatic polymorphism: a review including 1023 strains of the Mediterranean area, with special reference to Algeria. Acta trop 118: 80-86. Link: https://goo.gl/L3r5kz

33. Pratlong F, Lami P, Ravel C, Balard Y, Dereure J, et al. (2013) Geographica distribution and epidemiological features of Old World Leishmania infantum and Leishmania donovani foci, based on the isoenzyme analysis of 2277 strains. Parasitol 140: 423-434. Link: https://goo.gl/JXLGDz

34. Chaara D, Haouas N, Dedet JP, Babba H, Pratlong F (2014) Leishmaniases in Maghreb: an endemic neglected disease. Acta Trop 132: 80-93. Link: https://goo.gl/wYMa4r

35. Harrat Z, Belkaid M (2003) Leishmaniasis in Algiers: epidemiologic data. Bull Soc Pathol Exot 96: 212-214. Link: https://goo.gl/b8L6r6

36. Harrat Z, Addadi K, Belkaid M, Tabet-Derraz O (1992) Visceral leishmaniasis in Algeria. Cases reported of visceral leishmaniasis (1985-1990). Bull Soc Pathol Exot 85: 296-301. Link: https://goo.gl/5SURH4

37. Belazzoug S, Neal RA (1986) Failure of meglumine antimoniate to cure cutaneous lesions due to Leishmania major in Algeria. Trans Roy Soc Trop Med Hyg 80: 670-671. Link: https://goo.gl/c7igD3

38. Zait H, Ferhani Y, Achir I, Hamrioui B (2012) Study of 71 cases of visceral leishmaniasis diagnosed at the Mustapha University Hospital (Algiers) from 1998 to 2009. Med Mal Infect 42: 119-125. Link: https://goo.gl/2mcHuH

39. Adel A, Boughoufalah A, Saegerman C, De Deken R, Bouchene Z, et al. (2014) Epidemiology of visceral leishmaniasis in Algeria: an update. PLoS One 20: e99207. Link: https://goo.gl/McBT7a

40. Ciaramella P, Oliva G, Luna RD, Gradoni L, Ambrosio R, et al. (1997) A retrospective clinical study of canine leishmaniasis in 150 dogs naturally infected by Leishmania infantum. Vet Rec 141: 539-543. Link: https://goo.gl/CK4FG2

41. Miró G, Cardoso L, Pennisi MG, Oliva G, Baneth G (2008) Canine leishmaniosisnew concepts and insights on an expanding zoonosis: part two. Trends Parasitol 24: 371-377. Link: https://goo.gl/Qaoxil

42. Noli C, Auxilia ST (2005) Treatment of canine Old World visceral leishmaniasis: a systematic review. Vet Dermatol 16: 213-232. . Link: https://goo.gl/3THDct

43. Denerolle P, Bourdoiseau G (1999) Combination allopurinol and antimony treatment versus antimony alone and allopurinol alone in the treatment of canine leishmaniasis (96 cases). J Vet Inter Med 13: 413-415. Link: https://goo.gl/gpe3cY

44. Vercammen F, De Deken R (1995) Treatment of canine visceral leishmaniasis with allopurinol. Vet Rec. Link: https://goo.gl/QcwNxg

45. Gramiccia, L. Gradoni, Orsini S (1992) Decreased sensitivity to meglumine antimoniate (Glucantime) of Leishmania infantum isolated from dogs after several courses of drug treatment. Ann Trop Med Parasitol 86: 613-620. Link: https://goo.gl/8kFHqk

46. Aït-Oudhia K, Gazanion E, Sereno D, Oury B, Dedet JP, et al. (2012) In vitro susceptibility to antimonials and amphotericin B of Leishmania infantum strains isolated from dogs in a region lacking drug selection pressure. Vet Parasitol 187: 386-393. Link: https://goo.gl/iYksT2

47. Seblova V, Oury B, Eddaikra N, Aït-Oudhia K, Pratlong F, et al. (2014) Transmission potential of antimony-resistant Leishmania field isolates. Antimicrob Agents Chemother 58: 6273-6276. Link: https://goo.gl/3i5dGU

48. Sereno D, Holzmuller P, Lemesre JL (2000) Efficacy of second line drugs on antimonyl-resistant amastigotes of Leishmania infantum. Acta Trop 74: 25-31. Link: https://goo.gl/qUnx3G

Citation: Eddaikra N, Ait-Oudhia K, Oury B, Farida MM, Harrat Z, et al. (2017) Leishmania antimony resistance/susceptibility in Algerian foci. Open J Trop Med 1(1): 024-032. 
49. Vanaerschot M, Maes I, Ouakad M, Adaui V, Maes L, et al. (2010) in vitro and in vivo survival of clinical Leishmania donovani strains. PLoS One. Link: https://goo.gl/DT6XVP

50. Ait-Oudhia K, Gazanion E, Oury B, Vergnes B, Sereno D (2011) The fitness of antimony-resistant Leishmania parasites: lessons from the field. Trends Parasitol 27: 141-142.

51. Lukaszczyk L, Zyrnicki W (2010) Speciation analysis of $\mathrm{Sb}(\mathrm{III})$ and $\mathrm{Sb}(\mathrm{V})$ in antileishmaniotic drug using Dowex $1 \times 4$ resin from hydrochloric acid solution. J Pharm Biomed Anal 52: 747-751. Link: https://goo.gl/L2AAgr

52. Berman JD (1984) Leishmania tropica: quantitation of in vitro activity of antileishmanial agents by Giemsa staining, viability, and $3 \mathrm{H}$-formycin $\mathrm{B}$ incorporation. J Parasitol 70: 561-562. Link: https://goo.gl/6rgpqX

53. Seifert K, Escobar P, Croft SL (2010) In vitro activity of anti-leishmanial drugs against Leishmania donovani is host cell dependent. J Antimicrob Chemother 65: 508-511. Link: https://goo.gl/E9PCuH

54. Gebre-Hiwot A, Tadesse G, Croft SL, Frommel D (1992) An in vitro model for screening antileishmanial drugs: the human leukaemia monocyte cell line, THP-1. Acta Trop 51: 237-245. Link: https://goo.gl/qNggDe

55. van den BE, Schoone GJ, England P, Faber D, Orrling KM, et al. (2014) Simple colorimetric trypanothione reductase-based assay for high-throughput screening of drugs against Leishmania intracellular amastigotes. Antimicrob Agents Chemother 58: 527-535. Link: https://goo.gl/fwTB3v

56. Sereno D. Roy G, Papadopoulou B, Ouellette M (2001) DNA transformation of Leishmania infantum axenic amastigotes and their use in drug screening Antimicrob Agents Chemother 45: 1168-1173. Link: https://goo.gl/XeytK9

57. Sereno D, Cordeiro da SA, Mathieu DF, Ouaissi A (2007) Advances and perspectives in Leishmania cell based drug screening procedures. Parasito Inter 56: 3-7. Link: https://goo.gl/bdjRmH

58. De La Llave E, Lecaoeur H, Besse A, Milon G, Prina E, et al. (2011) A combined luciferase imaging and reverse transcription polymerase chain reaction assay for the study of Leishmania amastigote burden and correlated mouse tissue transcript fluctuations. Cell Microbiol 13: 81-89. Link: https://goo.gl/k2JJV2

59. Lang T, Lecoeur H, Prina E (2009) Imaging Leishmania development in their host cells. Trends Parasitol 25: 464-473. Link: https://goo.gl/NoEyBn

60. Hadighi R, Moheballi M, Boucher P, Hajjaran H, Kamesipour A, et al. (2006) Unresponsiveness to Glucantime treatment in Iranian cutaneous leishmaniasis due to drug-resistant Leishmania tropica parasites. PLoS Med. Link: https://goo.gl/uHHxmf

61. Lachaud L, Bourgeois N, Plourde M, Leprohon P, Bastien P, et al. (2009) Parasite susceptibility to amphotericin $B$ in failures of treatment for visceral leishmaniasis in patients coinfected with HIV type 1 and Leishmania infantum. Clin Infec Dis 48: 16-22. Link: https://goo.gl/Hm66Bp

62. Antoniou M, Douglerakis C, Pratlong F, Dedet JP, Tselentis Y (2004) Treatment failure due to mixed infection by different strains of the parasite Leishmania infantum. Am J Trop Med Hyg 71: 71-72. Link: https://goo.gl/jQoq41

63. Forestier CL, Späth GF, Prina E, Dasari S (2015) Simultaneous multi-parametric analysis of Leishmania and of its hosting mammal cells: a high content imaging-based method enabling sound drug discovery process. Microb Path 88: 103-108. Link: https://goo.gl/do4Ro7

64. Gupta N, Goyal N, Rastogi AK (2001) In vitro cultivation and characterization of axenic amastigotes of Leishmania. Trends Parasitol 17: 150-153. Link: https://goo.gl/SdLxfh

65. Sereno D, Lemesre JL (1997) Use of an enzymatic micromethod to quantify amastigote stage of Leishmania amazonensis in vitro. Parasitol Res 88: 401 403. Link: https://goo.gl/9NFxZ5

66. Lira R, Sundar S, Makharia A, Kenney R, Gam A, et al. (1999) Evidence that the high incidence of treatment failures in Indian kala-azar is due to the emergence of antimony-resistant strains of Leishmania donovani. J Infec Dis 180: 564-567. Link: https://goo.gl/9vYYua

67. Yardley V, Yardley V, Ortuno N, Llanos-Cuentas A, Chappuis F, et al. (2006) American tegumentary leishmaniasis: is antimonial treatment outcome related to parasite drug susceptibility? J Infec Dis 194: 1168-1175. Link: https://goo.gl/eQCCEe

68. Sundar S, Pai K, Kumar R, Pathak TK, Gam AA, et al. (2001) Resistance to treatment in Kala-azar: speciation of isolates from northeast India. Am J Trop Med Hyg 65: 193-196. Link: https://goo.gl/Bn2ezg

69. Vermeersch M, Da Luz RI, Toté K, Timmermans JP, Cos P, et al. (2009) In vitro susceptibilities of Leishmania donovani promastigote and amastigote stages to antileishmanial reference drugs: practical relevance of stagespecific differences. Antimicrob Agents Chemother 53: 3855-3859. Link: https://goo.gl/L7USV5

70. Vergnes B, Gourbal B, Girard I, Sundar S, Drummelsmith J, et al. (2007) proteomics screen implicates HSP83 and a small kinetoplastid calpain-related protein in drug resistance in Leishmania donovani clinical field isolates by modulating drug induced programmed cell death. Mol Cell Proteomics 6: 88 101. Link: https://goo.gl/9wj3Po

71. Mears ER, Modabber F, Don R, Johnson GE (2015) A Review: The current in vivo models for the discovery and utility of new anti-leishmanial drugs targeting cutaneous leishmaniasis. PLoS Negl Trop Dis. Link: https://goo.gl/q2ea6D

72. Gupta S, Nishi (2011) visceral leishmaniasis: experimental models for drug discovery. Indian J Med Res 133: 27-39. Link: https://goo.gl/5YBoEp

73. Eddaikra N, Kherachi Djenad I, Benbetka S, Benikhlef R, Ait Oudhia K, et al. (2016) Development of a murine infection model with Leishmania killicki, responsible for cutaneous leishmaniosis in Algeria: application in pharmacology. BioMed Res Inter. Link: https://goo.gl/wGVuoj

74. Ashutosh, Sundar S, Goyal N (2007) Molecular mechanisms of antimony resistance in Leishmania. J Med Microbiol 56: 143-153. Link: https://goo.gl/Mp2Mpo

75. Cunningham ML, Fairlamb AH (1995) Trypanothione reductase from Leishmania donovani. Purification, characterisation and inhibition by trivalent antimonials. Europ J Biochem 230: 460-468. Link: https://goo.gl/wy76ED

76. Wyllie S, Cunningham ML, Fairlamb AH (2004) Dual action of antimonial drugs on thiol redox metabolism in the human pathogen Leishmania donovani. J Biol Chem 279: 39925-39932. Link: https://goo.gl/wi7jVf

77. Mandal G, Wyllie S, Singh N, Sundar S, Fairlamb AH, et al. (2007) Increased levels of thiols protect antimony unresponsive Leishmania donovani field isolates against reactive oxygen species generated by trivalent antimony. Parasitol 134: 1679-1687. Link: https://goo.gl/Kwiavq

78. Marquis N, Gourbal B, Rosen BP, Mukhopadhyay R, Ouellette M (2005) Modulation in aquaglyceroporin AQP1 gene transcript levels in drug-resistant Leishmania. Mol Microbiol 57: 1690-1699. Link: https://goo.gl/1bLt9M

79. Mittal MK, Rai S, Ashutish R, Gupta S, Goyal N (2007) Characterization of natural antimony resistance in Leishmania donovani isolates. Am J Trop Med Hyg 76: 681-688 Link: https://goo.gl/EksF6V

80. Wyllie S, Mandal G, Sundar S, Fairlamb AH, Chatterjee M (2010) Elevated levels of tryparedoxin peroxidase in antimony unresponsive Leishmania donovani field isolates. Mol Biochem Parasitol 173: 162-164. Link: https://goo.gl/5SeQN

81. Denton H, McGregor JC, Coombs GH (2004) Reduction of anti-leishmanial pentavalent antimonial drugs by a parasite-specific thiol dependent reductase TDR1. Biochem Journal 381: 405-412. Link: https://goo.gl/ZeFSmr

82. Zhou Y, Messier N, Ouellette M, Rosen BP, Mukhopadhyay R (2004) Leishmania major LmACR2 is a pentavalent antimony reductase that confers sensitivity to the drug Pentostam. Mol Biochem Parasitol 279: 37445-37451. Link: https://goo.gl/bgk4gw

Citation: Eddaikra N, Ait-Oudhia K, Oury B, Farida MM, Harrat Z, et al. (2017) Leishmania antimony resistance/susceptibility in Algerian foci. Open J Trop Med 1(1): 024-032. 
83. Grondin K, Haimeur A, Mukhuopadhyay R, Rosen BP, Ouellette M (1997) Coamplification of the gamma-glutamylcysteine synthetase gene gsh1 and of the $A B C$ transporter gene pgpA in arsenite-resistant Leishmania tarentolae. EMBO J 16: 3057-3065. Link:

84. Anderson T, Nikhoma S, Ecker A, Fidock D (2011) How can we identify parasite genes that underlie antimalarial drug resistance? Pharmacogenomics 12: 5985. Link: https://goo.gl/EPJFf7

85. Leprohon $P$, Légaré $D$, Raymond F, Madore E, Hardiman G, et al. (2009) Gene expression modulation is associated with gene amplification, supernumerary chromosomes and chromosome loss in antimony-resistant Leishmania infantum. Nuc Acid Res 37: 1387-1399. Link: https://goo.gl/SZ7peu

86. Ubeda JM, Légaré D, Raymond F, Ouameur AA, Boisvert S, et al. (2008) Modulation of gene expression in drug resistant Leishmania is associated with gene amplification, gene deletion and chromosome aneuploidy. Gen Biol. Link: https://goo.gl/Dg4iGK

87. Adaui V, Schnorbusch K, Zimic M, Gutiérrez A, Decuypere S, et al. (2010) Comparison of gene expression patterns among Leishmania braziliensis clinical isolates showing a different in vitro susceptibility to pentavalent antimony. Parasitol 3: 1-11. Link: https://goo.gl/oKijJp
88. Mukherjee A, Padmanabhan PK, Singh S, Roy G, Girard I, et al. (2007) Role of $A B C$ transporter MRPA, gamma-glutamylcysteine synthetase and ornithine decarboxylase in natural antimony-resistant isolates of Leishmania donovani. J Antimicrob Chemother 59: 204-211. Link: https://goo.gl/s6DQBx

89. Kumar D, Kulshrestha A, Singh R, Salotra P (2009) In vitro susceptibility of field isolates of Leishmania donovani to Miltefosine and amphotericin $\mathrm{B}$. correlation with sodium antimony gluconate susceptibility and implications for treatment in areas of endemicity. Antimicrob Agents Chemother 53: 835838. Link: https://goo.gl/MoAw5X

90. Rojas R, Valderama L, Valderama M, Verona MX, Ouellette M, et al. (2006) Resistance to antimony and treatment failure in human Leishmania (Viannia) infection. J Infec Dis 193: 1375-1383. Link: https://goo.gl/v92voA

91. Jeddi F, Mary C, Aoun K, Harrat Z, Bouratbine A, et al. (2014) Heterogeneity of molecular resistance patterns in antimony-resistant field isolates of Leishmania species from the western Mediterranean area. Antimicrob Agents Chemother 58: 4866-4874. Link: https://goo.gl/Fb9gSA

92. t'Kindt R, Scheltema RA, Jankevics A, Brunker K, Rijal S, et al. (2010) Metabolomics to unveil and understand phenotypic diversity between pathogen populations. PLoS Negl Trop Dis 4: 904. Link: https://goo.gl/1RRhF7

Copyright: () 2017 Eddaikra N, et al. This is an open-access article distributed under the terms of the Creative Commons Attribution License, which permits unrestricted use, distribution, and reproduction in any medium, provided the original author and source are credited. 